\title{
Adolescência em foco: contribuições para a psicologia e para a educação
}

\section{Review Adolescence in focus: contributions to psychology and education}

\section{Reseña Adolescencia en el foco: contribuciones a la psicología y la educación}

\author{
Fabíola Batista Gomes Firbida \\ Universidade Estadual Paulista Júlio de Mesquita Filho - UNESP - Assis
}

Leal, Z. F.R.G; Facci, M. G. D.; Souza, M. P. R. (Orgs.), (2014) Adolescência em foco: Contribuições para a Psicologia e para a Educação. Maringá: EDUEM.

O livro tem como foco o tema da adolescência, na perspectiva da Psicologia Histórico-Cultural, que rompe com a visão pejorativa de adolescência. Aborda este período do desenvolvimento vinculado a homens reais que precisam ser entendidos nesta realidade concreta, ao mesmo tempo desigual, desumanizada, mas que nos incita a problematizar a forma como o adolescente está sendo tratado e propor soluções.

No Prefácio, Elenita Tanamachi, referência e pioneira em trabalhos voltados à educação dentro da abordagem crítica em Psicologia Escolar, denota a importância deste livro para "transformar a realidade da psicologia e da educação". O Capítulo I, desenvolvido por Marilda Facci e Zaira Leal, propõe o estudo da adolescência por meio da abordagem da Psicologia Histórico-Cultural em contraposição à visão biologizante e naturalizante. Esclarecem que este período da vida é uma construção história caracterizada por formações psíquicas novas, por períodos de crises que redirecionaram a forma como o adolescente relaciona-se com o meio e com as pessoas. Caracteriza-se, ainda, pela mudança dos interesses, pela maior capacidade de abstração, pela formação de conceitos e pelo desenvolvimento de sua autoconsciência.

O Capitulo II, de autoria de Gisele Mascagna e Marilda Facci, discute o desenvolvimento das funções psicológicas superiores, a formação de conceitos e a atividade principal na adolescência e traz dados da pesquisa em que as autoras investigam, com os próprios adolescentes, qual a sua concepção de adolescência. As autoras afirmam que as condições concretas determinam o conteúdo de cada estágio do desenvolvimento. Portanto, conforme a exigência da realidade, o sujeito irá responder ativamente com uma atividade dominante; que no caso do adolescente, é a comunicação íntima pessoal e a atividade profissional. Por fim, trazem os dados da pesquisa com adolescentes entre 13 a 15 anos que cursavam a $8^{a}$ série em 2008 , com o objetivo de investigar o que estes entendem por adolescência e "qual a atividade dominante na relação com a sociedade", ficando evidente na fala deles a concepção dominante de adolescência.

O Capitulo III é parte da tese intitulada Educação escolar e constituição da consciência: um estudo com adolescentes a partir da Psicologia Histórico-Cultural, desenvolvido por Záira Leal sob a orientação de Marilene Proença. As autoras apresentam dados coletados com adolescentes entre 16 a 18 anos do Ensino Médio, sobre como estes vivenciam a adolescência e o que significa para eles ser adolescente em nossa sociedade. Dentre as informações apresentadas pelos adolescentes, Záira e Marilene identificaram a "mudança do lugar social" que revela o conflito entre aquilo que o adolescente pensa sobre o seu lugar ocupado e o como os pais, professores e a sociedade de forma geral, o concebe. Nas considerações finais, apresentam uma análise bastante crítica da nossa sociedade capitalista e por fim, evidenciam a falha da educação escolar ao não garantir ao adolescente a apropriação do conhecimento científico.

O Capítulo IV traz dados de parte da pesquisa realizada no mestrado pela Ana Karina A. Checchia, orienta- 
da pela professora Marilene Proença. O público alvo são adolescentes das classes populares, que estão cursando a oitava série do Ensino Fundamental. O objetivo do capítulo é identificar os conflitos presentes na relação pedagógica entre professores e alunos, a partir da escuta dos adolescentes e dos docentes. As autoras constataram que tais conflitos são reflexos da visão negativa da adolescência; no entanto, em contraposição, também identificam que alguns professores desejam romper com esta concepção pessimista. Evidenciam a capacidade do adolescente em perceber na atitude de alguns professores a visão pejorativa da adolescência, bem como a possibilidade de outros docentes desenvolverem uma atitude de escuta, de acolhida, de respeito. Portanto, concluem que mesmo diante da tendência em perpetuar uma atitude negativa da adolescência, há professores que na relação pedagógica rompem com o estereótipo do adolescente violento, rebelde, marginal, o que significa um avanço na possibilidade de investir naquilo que o aluno tem de potencial e por isso, levar mais a sério o investimento no conhecimento científico, acreditando que este será importante para que o aluno modifique a sua realidade e a si mesmo.

O Capítulo $V$ é referente a um estudo de caso de dois adolescentes que cumprem medidas socioeducativas em meio aberto, parte da dissertação de Vania Calado sob a orientação de Marilene Proença. As autoras investigam como a escola pode ser uma produtora de violência e qual a relação entre esta violência e a questão de gênero na adolescência.

No último Capítulo, o VI, Marilene Proença e Marcelo Domingues Roman abordam a adolescência em conflito com a lei, mas neste capítulo, a medida socioeducativa aplicada é em regime privativo de liberdade, isto é, internação em estabelecimento educacional. Os autores enfocam o processo de desumanização dos adolescentes em conflito com a lei a partir da análise de três dimensões: a ideológica, a insti- tucional e a ontológica. Na dimensão ideológica, destacam a concepção abstrata do adolescente, ou seja, entendem o ato infracional desvinculado das condições concretas de vida, o que leva à naturalização e à explicação da infração baseada em defeitos no cérebro (biologização) e, portanto, desconsiderando a multideterminação do comportamento dos adolescentes. Na dimensão institucional, retratam a falta de preparo de policiais, promotores e juízes no cumprimento dos direitos previstos pelo Estatuto da Criança e do Adolescente (ECA, 1990) desde o momento em que o adolescente é pego no ato infracional até a decisão judicial pela internação, principalmente no que se refere ao critério de inimputabilidade penal de crianças e adolescentes.

$\mathrm{Na}$ dimensão ontológica, os autores saem da explicação aparente do ato infracional para compreendê-lo dentro de um sistema capitalista desumanizado, que separa o homem de sua produção. Utilizam para esta reflexão o conceito de alienação abordado por Marx, em que trabaIhador e mercadoria estão em uma relação de estranheza. Fazem uma relação desta realidade que não é consciente ou que está obscurecida para estes adolescentes em sua maioria pobres, provenientes das classes trabalhadoras e que, portanto, leva-os ao rompimento do convívio social por se sentirem atraídos pelo desejo de possuir objetos, dinheiro, drogas, armas que acreditam poderem camuflar os sentimentos de marginalidade e de inferioridade a que são submetidos diariamente.

Para finalizar, acreditamos que o livro apresenta diversos assuntos ao tratar sobre a adolescência, o que torna a leitura mais atraente a cada capítulo. Além de trazer especificações do trabalho com o adolescente, a leitura contribui para uma reflexão que vai além da aparência, das opiniões pessimistas, naturalizantes e abstraídas deste ser humano, o que nos instiga a refletir sobre nosso próprio trabalho e nossas convicções sobre a adolescência.

\section{Sobre a autora}

Fabíola Batista Gomes Firbida (fabiolabgomes@hotmail.com)

Doutoranda em Psicologia na Universidade Estadual Paulista Júlio de Mesquita Filho - UNESP, Câmpus de Assis. Mestra em Psicologia pela Universidade Estadual de Maringá - UEM. 